\section{Utah law triggers university row over concealed weapons}
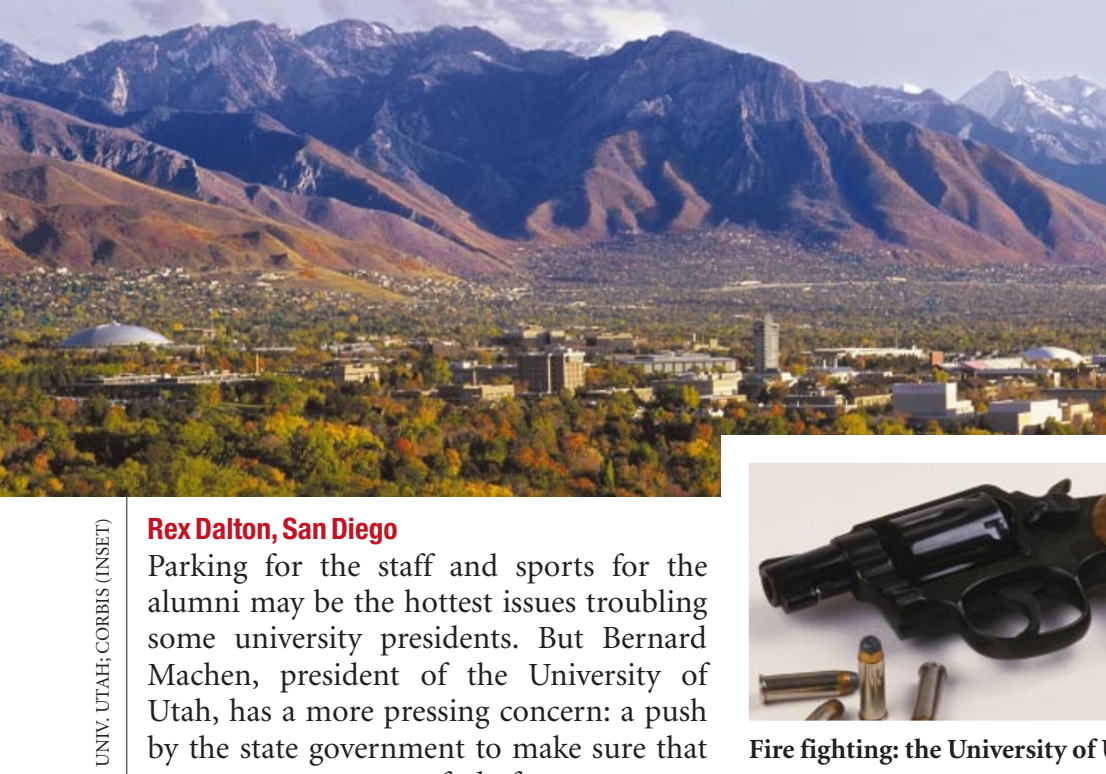

Rex Dalton, San Diego

Parking for the staff and sports for the alumni may be the hottest issues troubling some university presidents. But Bernard Machen, president of the University of Utah, has a more pressing concern: a push by the state government to make sure that everyone on campus feels free to carry a concealed firearm.

Scientists at the Salt Lake City campus are up in arms themselves over the state's push to ensure that guns are permitted, and seen to be permitted. "The situation is bizarre," says Rob MacLeod, a bioengineer at the university who specializes in electrocardiology. "I tell my friends about this and they look at me like I am from another planet."

The drive is backed by the state legislature and the Utah attorney general, Mark Shurtleff. "The fear of concealed weapons is groundless and irrational," Shurtleff says. But some professors say they will consider resigning or retiring if the state is successful.

The issue has arrived on campus through a wider movement by US gun advocates and conservatives to enact state laws permitting the carrying of concealed weapons as a potential deterrent to crime. Like many states, Utah passed such laws several years ago, allowing anyone who is over 21 years old and not a felon to obtain such a permit. The permits are easily acquired by most adults.

Shurtleff issued an opinion last November saying that nine state-funded colleges cannot have policies that prohibit the carrying of concealed guns. Utah's effort to enforce the concealed-weapon law on campuses is thought to be the first of its type.

The University of Utah — the largest and most powerful of the nine - is trying to take a stand against the Shurtleff ruling. In March, it asked the US District Court in Salt Lake City to issue an opinion to allow it to enforce a policy banning concealed weapons on campus. No hearing has been set yet, but the university is hoping for a decision late this year.

None of the other eight state-funded

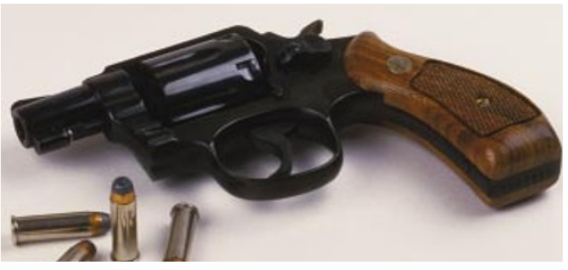

Fire fighting: the University of Utah (top) wants to stop students from carrying guns on campus.

universities has joined the court action perhaps fearing financial retribution from the legislature, which holds their purse strings - and all of them are permitting concealed weapons on campus while they await the court's decision. Earlier this year, a committee of the legislature narrowly rejected a motion to cut Machen's pay in retaliation for his stance on the issue.

In documents submitted to the court, the university argues that it should be allowed to limit concealed weapons in order to create an environment in which people can exchange ideas freely, without fear of being shot.

"I don't see handguns being appropriate for classroom discussions," says computer scientist Christopher Johnson, director of the Scientific Computing and Imaging Institute at the university.

Professors and others opposed to the proposal are trying to collect the 30,000 signatures needed to force a statewide vote this November on a resolution that would exempt campuses from Utah's concealedweapons law.

"We're concerned about a tragedy in the making here," says chemist Peter Stang, dean of the university's College of Science. Johnson says that his wife, Katharine Coles, an English professor who is president-elect of the University of Utah's faculty senate, has been told that "distinguished members of the faculty have indicated they will leave" if the university is not successful in banning concealed weapons.

And ecologist Phyllis Coley says: "A colleague from New York called to say he is fearful of coming here to give a talk.”
Deep-sea nuggets prove irresistible to Indian miners

\section{K. S. Jayaraman, New Delhi}

India is set to go ahead with plans to mine millions of tonnes of manganese nodules from the Indian Ocean's floor, despite warnings from an environmental assessment that the project will disrupt deep-sea ecology.

The potato-shaped nodules are rich in manganese, copper, nickel, cobalt and iron. India has a shortage of some of these elements, and has purchased exclusive rights from the International Seabed Authority to mine the nodules from 150,000 square kilometres of the Indian Ocean. The country estimates that the reserves could be worth as much as $\$ 200$ billion.

But researchers at the National Institute of Oceanography (NIO) in Goa, who undertook a survey to assess the environmental impact of mining operations, say that discharges of unwanted sediment during mining will upset the area's ecological balance.

To simulate the mining process, the researchers mimicked the release of sediment over a small area 5,500 metres below the sea's surface.

During a nine-day experiment in 1997, they lifted about 580 tonnes of sediment from the sea floor and then released it five metres above the sea bed. They have since been tracking how the sediment plumes drift and what effect they have on the area's ecology.

The recently released report says that "noticeable changes were observed in the physical and biogeochemical properties" of the area. The sediment plumes migrated at least two kilometres from the drop site, and the abundance of fauna and bacteria decreased in the region, says marine geologist Anil Valsangkar, who led the study.

Valsangkar says that actual mining would cause much more disruption if, as is likely, the mining ships discharged the sediments at the sea's surface.

The Indian government will not say when it plans to begin the mining operation, but it has spent about $\$ 40$ million surveying the site, has bought a ship and is developing machinery for the purpose. NIO sources say that the environmental study was conducted to comply with the law, rather than to obtain clearance to proceed.

But critics have questioned the plan's economics, given that the nodules are so far below the sea's surface and that the site is $2,000 \mathrm{~km}$ away from India. 